\title{
The effects of inclusion level and source of sodium in diets for growing turkeys. A review
}

\author{
Z. Zduńczyk ${ }^{1}$ and J. Jankowski ${ }^{2,3}$ \\ IInstitute of Animal Reproduction and Food Research, Polish Academy of Sciences \\ Bydgoska 1/9, 10-243 Olsztyn \\ 2University of Warmia and Mazury in Olsztyn, Department of Poultry Science \\ M. Oczapowskiego 5,10-719 Olsztyn
}

KEY WORDS: Na salts, blood electrolytes, intestine, excreta moisture, tibia mineralization, growth, meat, turkey
Received: 20 January 2014

Revised: 21 February 2014

Accepted: 4 March 2014
${ }^{3}$ Corresponding author: e-mail: janj@uwm.edu.pl
ABSTRACT. This review briefly summarizes the results of recent studies investigating the effects of different dietary sodium $(\mathrm{Na})$ levels on gastrointestinal function, excreta moisture content, incidence of footpad dermatitis (FPD), tibia mineralization, and growth performance in turkeys. Research shows that an increase in the sodium content of turkey diets from $0.07 \%$ to approximately $0.22 \%$ led to minor changes in the gastrointestinal tract of birds, limited to increased hydration and decreased viscosity of small intestinal digesta, and that it had no significant influence on fermentation processes in the caecum. Dietary $\mathrm{Na}$ contributed to the development and severity of FPD in turkeys, despite its insignificant effect on excreta moisture content. Blood electrolyte concentrations were similar in turkeys fed sodium-deficient diets $(0.08 \%$ and less) and diets containing an excess of sodium $(0.17 \%-0.22 \%)$. No differences were observed in the immune responses of birds (percentages of T-cell subpopulations). Moderate levels of dietary $\mathrm{Na}(0.13 \%$ and $0.17 \%)$ improved tibia mineralization compared with diets containing lower $\mathrm{Na}$ levels $(0.12 \%$ and less). Nonetheless, an increase in $\mathrm{Na}$ inclusion rates from $0.17 \%$ to $0.22 \%$ and from $0.13 \%$ to $0.28 \%$ did not improve the parameters of tibia growth, mineralization, or breaking strength. Turkeys fed a diet with a low $\mathrm{Na}$ content (below $0.1 \%$ ) were characterized by a slower growth rate, and the noted trend was much more pronounced in the first 8 weeks than at the end of the rearing period. Dietary $\mathrm{Na}$ inclusion levels higher than those recommended by the National Research Council (NRC 1994) did not increase the final body weights of turkeys. The recommendations of the German Society of Nutrition Physiology (GfE 2004) more adequately reflect the actual sodium requirements of turkeys than the recommendations of the NRC (1994) and poultry breeding companies. In diets for younger turkeys, dietary sodium levels can be lowered to $0.13 \%$, $0.12 \%$ and $0.10 \%$ at $1-4,5-8$ and $9-12$ weeks of age, respectively, and in older birds the $\mathrm{Na}$ content of diets can be maintained at $0.09 \%$. The results of one experiment that examined the physiological effects of Na sources alternative to $\mathrm{NaCl}$ in turkey diets do not justify far-reaching conclusions. Further study is required to confirm the suitability of $\mathrm{NaHCO}_{3}$ and $\mathrm{Na}_{2} \mathrm{SO}_{4}$ as alternatives to $\mathrm{NaCl}$ in turkey nutrition. 


\section{Introduction}

The renin-angiotensin-aldosterone system, which controls circulating blood volume and the concentrations of sodium and potassium ions in bodily fluids, is also involved in the regulation of sodium balance, including $\mathrm{Na}$ intake and metabolism (Daniels et al., 2007). The mechanism responsible for transporting sodium and potassium cations and other components across the plasma membrane, important in many cellular functions, is known as the sodium-potassium pump, the sodium pump or $\mathrm{Na}(+)-\mathrm{K}(+)$-ATPase (Therien and Blostein, 2000). $\mathrm{Na}(+)-\mathrm{K}(+)$-ATPase, an integral membrane protein, couples this active transport process to the hydrolysis of the terminal phosphate bond of ATP (Kaplan, 2002). Sodium ions transport glucose and amino acids into the cell against their concentration- and potential gradients. Dietary $\mathrm{Na}$ status affects the performance of chickens, mRNA expression and the parameters of $\mathrm{Na}^{+} / \mathrm{K}^{+}$-ATPase activity in the jejunum (Gal-Gerber et al., 2003). Increased dietary sodium chloride concentrations reduce endogenous amino acid flow and influence the physiological response to the ingestion of phytic acid by broiler chickens (Cowieson et al., 2011).

The sodium pump, the first protein discovered as an ATP-dependent active ion transporter, whose ion pumping is central to renal function, plays a complex role in the regulation of salt and electrolyte homeostasis (Kaplan, 2008). Dietary sodium $\left(\mathrm{Na}^{+}\right)$and other monovalent minerals, potassium $\left(\mathrm{K}^{+}\right)$and chloride $\left(\mathrm{Cl}^{-}\right)$, are known as 'strong ions' due to their greater effect on the acid-base balance of body fluids than divalent ions such as calcium, magnesium, phosphate or sulphate (Mongin, 1980). Higher levels of $\mathrm{Na}$ and $\mathrm{K}$ are associated with a higher $\mathrm{pH}$ (i.e. alkalosis), while lower levels of $\mathrm{Cl}$ are linked with a lower $\mathrm{pH}$ (i.e. acidosis) (Mushtaq and Pasha, 2013).

Sodium deficiency in the human diet leads not only to rapid physiological (i.e. autonomic and endocrine) adjustments for protecting homeostasis, but also to profound behavioural changes (Johnson, 2007; Morris et al., 2008). In poultry, symptoms of sodium deficiency include anxiety and aggressive pecking. On the other hand, excessive sodium chloride intake in the typical Western diet has adverse effects on bone in the aging human population (Frassetto et al., 2008; Buehlmeier et al., 2012). The effect of dietary Na levels on bone mineralization in poultry is an important consideration in view of skeletal defects and deformities encountered in fast-growing birds (Oviedo-Rondon et al., 2006; Venäläinen et al., 2006; Nääs et al., 2009).
Since sodium metabolism and water balance are closely related, $\mathrm{Na}$ intake may regulate water intake and, indirectly, excreta moisture in poultry (Borges et al., 2003; Mushtaq et al., 2007, 2013). It is an important risk factor for excess litter moisture and leg problems, common in intensively farmed chickens and turkeys (Francesch and Brufau, 2004: Venäläinen et al., 2006).

The physiological and performance-related effects of different dietary inclusion levels of sodium, potassium and chloride have been extensively researched in broiler chickens (Eichner et al., 2007; Enting et al., 2009; Nääs et al., 2009; Koreleski et al., 2010, 2011; Jankowski et al., 2011a,b; Tykałowski et al., 2011; Zduńczyk et al., 2012; Arantes et al., 2013). Recent findings have been discussed in two review articles (Mushtaq and Pasha, 2013; Mushtaq et al., 2013). A few similar experiments have been performed on turkeys (Mayne et al., 2007; Jankowski et al., 2012 b,c; Lichtorowicz et al., 2012), but their results have not been summarized to date. In view of the above, the aim of this literature review was to analyse the effects of sodium, as well as potassium and chloride, on gastrointestinal function, excreta moisture content, FPD incidence, tibia mineralization and breaking strength, growth performance and slaughter quality of turkeys.

\section{Dietary electrolyte requirements of turkeys and electrolyte balance of feed}

NRC (1994) recommends $0.17 \%$ and $0.15 \%$ $\mathrm{Na}$ in weeks $1-4$ and 5-8, respectively, and $0.12 \%$ $\mathrm{Na}$ in subsequent feeding phases in turkeys. In the starter phase, the $\mathrm{K}$ and $\mathrm{Cl}$ contents of turkey diets should be $0.7 \%$ and $0.15 \%$, respectively (NRC, 1994). In subsequent months, the dietary $\mathrm{K}$ and $\mathrm{Cl}$ levels should be decreased from $0.6 \%$ to $0.4 \%$ and from $0.14 \%$ to $0.12 \%$, respectively. The GfE (2004) recommends lower $\mathrm{Na}$ levels, i.e. $0.13 \%$ during the first four weeks, followed by a $0.01 \%$ decrease in subsequent weeks to reach $0.09 \%$ in week 20 . According to the above recommendations, $\mathrm{Cl}$ levels should be equal to $\mathrm{Na}$ levels in turkey diets, and $\mathrm{K}$ content should be decreased from $0.35 \%$ at the beginning to $0.18 \%$ at the end of rearing. Poultry breeding companies recommend high $\mathrm{Na}$ levels throughout the rearing cycle of turkeys. According to British United Turkeys, $\mathrm{Na}$ and $\mathrm{Cl}$ contents should range from $0.15 \%$ to $0.18 \%$ and from $0.18 \%$ to $0.21 \%$, respectively, subject to the energy 
value of diets (Aviagen Turkeys, 2014). According to Hybrid Turkeys Inc., Na levels should be maintained at $0.16 \%$ to $0.18 \%$, and $\mathrm{Cl}$ content can be increased up to $0.29 \%$ (Hybrid Turkeys, 2014). Turkey diets without additional $\mathrm{NaCl}$ contain a small amount of sodium, a sufficient amount of chloride, and an excessive amount of potassium (Table 1). $\mathrm{NaCl}$ supplementation increases the content of both sodium and chloride in the diet to above the recommended levels.

The proportions of 'strong ions' in the diet determine the dietary electrolyte balance (DEB) calculated from the following equation (Mongin, 1981): $\mathrm{DEB}=\mathrm{Na} \mathrm{mEq} \cdot \mathrm{kg}^{-1}+\mathrm{K} \mathrm{mEq} \cdot \mathrm{kg}^{-1}-\mathrm{Cl} \mathrm{mEq} \cdot \mathrm{kg}^{-1}$. The optimum DEB value, resulting from the recommended dietary intakes of $\mathrm{Na}, \mathrm{K}$ and $\mathrm{Cl}$ in young turkeys, is $211 \mathrm{meq} \cdot \mathrm{kg}^{-1}$.

Table 1 data show that diets with different $\mathrm{Na}$ levels had DEB values close to $250 \mathrm{mEq} \cdot \mathrm{kg}^{-1}$, the value considered optimal in broiler chickens (Mongin, 1981; Borges et al., 2004; Mushtag et al., 2007). The high DEB values resulted from the high potassium content of soyabean meal, a major highprotein feed component in poultry diets (Frame et al., 2001; Jankowski et al., 2011b).

Table 1. Sodium chloride supplementation, sodium, potassium, chloride content, and dietary electrolyte balance (DEB) in turkey diets with low $(\mathrm{L})$, medium $(\mathrm{M})$ and high $(\mathrm{H})$ sodium levels (Jankowski et al., 2012c)

\begin{tabular}{llll}
\hline \multirow{2}{*}{ Indices } & \multicolumn{3}{l}{ Dietary sodium level } \\
\cline { 2 - 4 } & $\mathrm{L}$ & $\mathrm{M}$ & $\mathrm{H}$ \\
\hline NaCl addition, \% & 0.0 & 0.254 & 0.636 \\
Sodium content, \% & 0.034 & 0.134 & 2.82 \\
Potassium content, \% & 1.10 & 1.10 & 1.10 \\
Chloride content, \% & 0.17 & 0.32 & 0.59 \\
$\mathrm{DEB}, \mathrm{mEq} \cdot \mathrm{kg}^{-1}$ & 242 & 249 & 246 \\
\hline
\end{tabular}

The optimum DEB value of turkey diets remains debatable. Earlier studies have reported a decrease in the liveweight of young turkey poults at DEB of $250 \mathrm{mEq} \cdot \mathrm{kg}^{-1}$ or higher (Dewar, 1984, cited in Frame et al., 2001). Pang et al. (1979) observed relative functional renal insufficiency in young turkeys ( 5 to 10 days of age) offered saline drinking water. This is one of the reasons why the dietary Na level recommended for the youngest turkeys is much lower than that recommended for broiler chickens (0.17\% vs $0.20 \%)$ (NRC, 1994$)$.

According to Hooge et al. (1999), DEB is an index and several different combinations of $\mathrm{Na}, \mathrm{K}$ and $\mathrm{Cl}$ levels can be developed for any particular outcome, and other dietary factors may influence the productivity of birds. One such factor could be the use of $\mathrm{Na}$ sources alternative to $\mathrm{NaCl}$, including
$\mathrm{NaHCO}_{3}$ and $\mathrm{Na}_{2} \mathrm{SO}_{4}$, which do not contain chloride. Since sodium and chloride have opposite functions in maintaining DEB, DEB is low in diets containing $\mathrm{NaCl}$, whereas alternative $\mathrm{Na}$ sources may increase DEB values (Jankowski et al., 2012a).

\section{Effect of dietary Na on gastrointestinal function}

The results of experiments on broiler chickens indicate that water and feed intake are determined by the Na content of diets (Watkins et al., 2005). In a study by Jankowski et al. (2011a), a considerable increase in the Na content of broiler diets (from $0.02 \%$ to $0.17 \%$ ) significantly decreased the $\mathrm{pH}$ of small intestinal digesta and its dry matter concentration, and enhanced the activities of microbial $\beta$-glucosidase and $\beta$-glucuronidase in the caecal digesta. In our previous experiment, an increase in the $\mathrm{Na}$ content of broiler diets (from $0.16 \%$ to $0.29 \%$ ) led to a decrease in the dry matter content from $17.1 \%$ to $16.1 \%$ and viscosity of the intestinal digesta from 2.09 to $1.83 \mathrm{mPas}$ (Zduńczyk et al., 2012). No significant differences were found between treatments with respect to the activity levels of mucosal saccharase and maltase, whereas higher dietary $\mathrm{Na}$ concentrations increased the activity of aminopeptidase.

Selected parameters of small intestine function in young turkeys fed diets with a different $\mathrm{Na}$ content are presented in Table 2.

Table 2. Parameters of the small intestine in turkeys aged 8 weeks, fed diets with different $\mathrm{Na}$ contents (Jankowski et al., 2012a)

\begin{tabular}{lllllll}
\hline \multirow{2}{*}{ Parameter } & \multicolumn{7}{c}{ Dietary Na content, \% } & \multirow{2}{*}{ SEM } & $P$ \\
\cline { 2 - 6 } & 0.07 & 0.12 & 0.17 & 0.22 & & \\
\hline Full weight, g $\mathrm{kg}^{-1} \mathrm{BW}$ & $52.1^{\mathrm{a}}$ & $47.7^{\mathrm{a}}$ & $40.9^{\mathrm{b}}$ & $40.8^{\mathrm{b}}$ & 1.200 & $<0.001$ \\
Digesta dry matter, \% & $17.8^{\mathrm{a}}$ & $16.7^{\mathrm{b}}$ & $16.2^{\mathrm{b}}$ & $15.4^{\mathrm{c}}$ & 0.184 & $<0.001$ \\
Digesta viscosity, mPas & $2.07^{\mathrm{a}}$ & $1.74^{\mathrm{b}}$ & $1.66^{\mathrm{b}}$ & $1.55^{\mathrm{c}}$ & 0.038 & $<0.001$ \\
Digesta pH & $5.83^{\mathrm{a}}$ & $5.83^{\mathrm{a}}$ & $5.60^{\mathrm{a}}$ & $5.11^{\mathrm{b}}$ & 0.087 & 0.005 \\
\hline
\end{tabular}

${ }_{a, b, c}$ values within a row with different letter differ significantly at $P<0.05$

Table 2 data show that an increase in dietary $\mathrm{Na}$ led to a decrease in the weight of the small intestine, dry matter concentrations, viscosity and $\mathrm{pH}$ of digesta. Statistical analysis revealed that the full weight of the small intestine $(Y)$ was linearly dependent on $\mathrm{Na}$ levels in the diet $(X)$, according to the following formula: $Y=55.55-81.40 X ; R^{2}=0.904, P=0.049$. Similar, statistically significant regression equations were calculated for the dry matter, viscosity, and $\mathrm{pH}$ of digesta (Jankowski et al., 2012c). Differences in the parameters of small intestine function, noted between the groups, did not affect the weight and dry 
matter content of the caecal digesta. Higher concentrations of dietary sodium increased the activities of bacterial $\beta$-glucosidase, $\alpha$ - and $\beta$-galactosidase and $\beta$-glucuronidase, whereas SCFA concentrations in the caecal contents were not influenced by the applied dietary treatments.

In another experiment (Jankowski et al., 2012a), the amount of $\mathrm{Na}$ added to a diet $(0.08 \%$ or $0.18 \%)$ had no effect on the relative full weight of the small intestine, the viscosity or dry matter concentrations of the jejunal and ileal digesta in 18-weekold turkeys. The low Na level did not change the analysed gastrointestinal parameters, i.e. $\mathrm{pH}$, dry matter concentrations and digesta viscosity in the jejunum and ileum, as well as $\mathrm{pH}$, dry matter and ammonia concentrations, bacterial $\beta$-glucosidase and $\beta$-glucuronidase activities, and short-chain fatty acid concentrations in the caecum.

The results of experiments performed on turkeys (Jankowski et al., 2012a,c) and broiler chickens (Jankowski et al., 2011b; Zduńczyk et al., 2012) were similar. An increase in the sodium content of broiler diets, from $0.16 \%$ to approximately $0.30 \%$, led to minor changes in the gastrointestinal tract of birds, limited to increased hydration and decreased viscosity of small intestinal digesta and enhanced activity of aminopeptidase in the intestinal mucosa, whereas that it did not significantly influence fermentation processes in the caecum.

\section{Effect of dietary Na on excreta moisture and FPD incidence}

Leg disorders, including FPD, are a common problem in intensive poultry farming. FPD is often caused by a high litter moisture content associated with nutritional factors (Francesch and Brufau, 2004; Eichner et al., 2007; Mayne et al., 2007; Cengiz et al., 2012). Soyabean meal-based diets have relatively high $\alpha$-galactoside concentration (above $2 \%$ ), which increases the risk of FPD in turkeys (Jankowski et al., 2009). The development and severity of FPD can be reduced if whole grain wheat is used as a partial substitute for a pelleted diet, as it increases the physiological role of the proventriculus and gizzard, thus slowing down digestive transit (Jankowski et al., 2013; Zduńczyk et al., 2013).

Dietary sodium intake is often increased to stimulate the growth of birds, leading to excess litter wetness and excreta moisture. As demonstrated by many authors (Murakami et al., 2001; Borges et al., 2003; Vieira et al., 2003; Mushtaq et al., 2007), an increase in the $\mathrm{Na}$ content of broiler diets enhances water intake and decreases the dry matter content of droppings.

Table 3 presents the results of experiments investigating the effects of different sodium levels in diets fed to turkeys of different ages. The sodium content of diets, which in the first experiment ranged from $0.03 \%$ to $0.28 \%$, had an insignificant influence on excreta moisture. Only in experiment $2 \mathrm{~b}$, the droppings of 13-week-old turkey hens fed a diet with the highest $\mathrm{Na}$ content $(0.18 \%)$ contained significantly less dry matter, compared with hens fed the diet with the lowest $\mathrm{Na}$ content $(0.08 \%)$.

Table 3. Dry matter content of excreta (\%) and footpad dermatitis (FPD) scores in turkeys fed diets with different levels of sodium (Lichtorowicz et al., 2012; Jankowski et al., 2012a,c)

\begin{tabular}{|c|c|c|c|c|c|c|}
\hline \multirow{2}{*}{$\begin{array}{l}\text { Sex and age of turkeys } \\
\text { (No. of experiment) }\end{array}$} & \multicolumn{6}{|c|}{ Na content, \% } \\
\hline & 0.03 & 0.08 & 0.13 & 0.18 & 0.22 & 0.28 \\
\hline \multicolumn{7}{|l|}{$q-6$ weeks $(1)$} \\
\hline DM content & 18.6 & 18.4 & 18.5 & 18.4 & 19.0 & 17.4 \\
\hline FPD & $3.0^{c}$ & $3.2^{\mathrm{bc}}$ & $3.4^{\mathrm{b}}$ & $3.5^{\mathrm{b}}$ & $3.8^{\mathrm{ab}}$ & $4.0^{\mathrm{a}}$ \\
\hline \multicolumn{7}{|l|}{$q-7$ weeks (2a) } \\
\hline DM content & - & 20.4 & 20.2 & 19.9 & - & - \\
\hline FPD & - & 1.5 & 1.7 & 1.8 & - & - \\
\hline \multicolumn{7}{|l|}{ q -13 weeks (2b) } \\
\hline DM content & - & $22.2^{\mathrm{a}}$ & $21.2^{\mathrm{ab}}$ & $21.1^{\mathrm{b}}$ & - & - \\
\hline FPD & - & 2.6 & 2.7 & 2.8 & - & - \\
\hline \multicolumn{7}{|l|}{$\widehat{o}-8$ weeks (3a) } \\
\hline DM content & - & 19.0 & 19.4 & 19.2 & 19.0 & - \\
\hline FPD & - & $1.7^{\mathrm{b}}$ & $1.8^{\mathrm{ab}}$ & $1.7^{\mathrm{b}}$ & $2.0^{\mathrm{a}}$ & - \\
\hline \multicolumn{7}{|l|}{$\delta^{\lambda}-18$ weeks (3b) } \\
\hline DM content & - & 20.5 & 20.0 & 20.2 & 19.9 & - \\
\hline FPD & - & $3.2^{b}$ & $3.3^{b}$ & $3.5^{\mathrm{a}}$ & $3.5^{\mathrm{a}}$ & - \\
\hline
\end{tabular}

In experiments 1 and $3 \mathrm{a}$ and $\mathrm{b}$, dietary sodium had no significant effect on excreta moisture, but increasing $\mathrm{Na}$ levels enhanced the severity of FPD. Abd El-Wahab et al. (2011) also observed a higher incidence of FPD in turkeys fed diets containing $0.31 \% \mathrm{Na}$ and $1.53 \% \mathrm{~K}$, as compared with birds that received lower levels of dietary electrolytes $(0.16 \%$ and $0.78 \%$, respectively). Differences in excreta moisture resulting from sodium intake were smaller in turkeys than in chickens (Jankowski et al., 2011a) fed diets containing $0.15 \%, 0.20 \%$ and $0.25 \% \mathrm{Na}$. The above could be due to lower feed intake relative to the body weight of growing turkeys, and their lower renal efficiency with regard to water excretion, which was also observed in a study of the toxic effect of saline water in young turkeys (Pang et al., 1979).

In all three experiments, the symptoms of FPD intensified with increasing dietary $\mathrm{Na}$ levels which, however, did not increase excreta moisture. This suggests that a higher $\mathrm{Na}$ content of excreta contributes 
to FPD not only through increased litter wetness but also due to a strong effect exerted by $\mathrm{Na}$ contained in excreta. Further research is needed, however, to verify the above hypothesis and provide evidence of the 'relative functional renal insufficiency' in young turkeys described by Pang et al. (1979).

\section{Effect of dietary Na on blood electrolyte concentrations and the immune response of turkeys}

The effect of different dietary sodium levels on mineral balance in young turkeys was evaluated based on blood electrolytes (Lichtorowicz et al., 2012). In six-week-old turkeys fed six diets whose sodium content ranged from $0.02 \%$ to $0.26 \%$, lower concentrations of $\mathrm{Cl}$ and $\mathrm{P}$, and higher $\mathrm{Ca}$ levels were noted in the group fed a diet with the lowest dietary inclusion of sodium and without additional $\mathrm{NaCl}$. Similar results were reported by Tykałowski et al. (2011) who found that only a sodium-deficient diet caused significant changes in blood electrolyte levels in broiler chickens. In other experiments (Mushtaq et al., 2007; Olanrewaju et al., 2007), differences in serum electrolyte concentrations were not observed in birds fed diets with a moderate $\mathrm{Na}$ content. The findings of Mushtaq et al. (2007) show that a high $\mathrm{Cl}$ content of diets $(0.3 \%-0.5 \%)$ causes a linear increase in serum $\mathrm{Na}$ levels and a quadratic decrease in serum $\mathrm{K}$ concentrations.

More pronounced differences were noted in a study of 18 -week-old turkeys fed diets with four $\mathrm{Na}$ levels, $0.07 \%, 0.12 \%, 0.17 \%$ and $0.22 \%$ (Jankowski et al., 2012c). Dietary sodium $(X)$ linearly increased serum Na levels $(Y)$, as follows: $Y=149.5+14 X$ $\left(R^{2}=0.891, P=0.056\right)$. Identical, significant trends were observed for the serum levels of potassium $\left(R^{2}=0.904\right)$ and phosphorus $\left(R^{2}=0.945\right)$. The applied dietary treatments had no effect on the concentrations of $\mathrm{Cl}, \mathrm{Ca}$ and $\mathrm{Mg}$ in the blood serum of turkeys.

In an experiment on chickens, excess sodium increased circulating blood volume and decreased lymphocyte counts (Ekanayake et al., 2004). In another study, DEB (increased with the addition of $\mathrm{NH}_{4} \mathrm{Cl}$ or $\mathrm{NaHCO}_{3}$ ) was found to influence not only the growth performance of broilers, but also their immune response (Szabó et al., 2011).

In an experiment performed on young turkeys (Tykałowski et al., 2011), only a sodium-deficient diet $(0.02 \%)$ without supplemental $\mathrm{NaCl}$ decreased the counts of CD4+, CD8+ and CD4+CD8+ T cells, but the noted differences were statistically non- significant relative to the $0.07 \%-0.26 \% \mathrm{Na}$ groups. The above was also due to relatively high variation in the analysed parameters that were not linearly dependent on dietary $\mathrm{N}$ levels.

The results of our experiments show that $\mathrm{NaCl}$ supplementation had only a minor influence on the ratios of T-cell subpopulations and microelement concentrations in the blood serum of turkeys. Thus, the effect of dietary sodium on mineral balance in turkeys should not be determined based exclusively on blood electrolytes and T-cell profile.

\section{Effect of dietary Na on tibia mineralization}

Leg deformities and abnormalities, which adversely affect the welfare and growth rate of birds and carcass quality, are among the most common health problems encountered in intensive poultry farming (Oviedo-Rondon et al., 2006; Venäläinen et al., 2006; Nääs et al., 2009). Genetic progress and selection for a fast growth rate are accompanied by increased susceptibility of birds to infections (Leshchinski and Klasing, 2001) and heat stress (Lara and Rostagno, 2013). The cortical bone of fast-growing meat-type chickens has been found to be less well mineralized and more porous than that of slow-growing strains (Leterrier and Nys, 1992; Wiliams et al., 2000).

Another reason for leg deformities and injuries in fast-growing birds is a nutritional deficiency, including insufficient amounts of the biologically active form of vitamin $\mathrm{D}_{3}$ (Faruga et al., 2009; Zhou et al., 2011). Sodium-calcium interactions also play a vital role in the pathogenesis of skeletal muscle damage in broiler chickens (Sandercock and Mitchell, 2004), which may lead to locomotion problems. In turkeys, leg problems often result from selection for a rapid increase in body weight and breast muscle yield (Crespo et al., 2000).

Research suggests that the most common reason for insufficient bone mineralization is mineral metabolism disorders, in particular a deficiency of calcium and phosphorus (Kestin et al., 2001; Rao et al., 2003; Venäläinen et al., 2006; Tatara et al., 2011). Little attention has been paid to the effects of essential dietary electrolytes $(\mathrm{Na}, \mathrm{K}$ and $\mathrm{Cl})$ on bone mineralization in young birds. Murakami et al. $(1997 a, b)$ reported that in broiler chickens, the ash content of bones decreased with increasing dietary sodium levels and increased in response to higher dietary intake of chloride. In a study by Jankowski et al. (2011b), both the lowest and highest dietary 
Table 4. Growth parameters, mineral composition, geometrical and mechanical properties of the tibia in turkeys (Jankowski et al., 2012c).

\begin{tabular}{lcccccc}
\hline \multirow{2}{*}{ Indices } & \multicolumn{3}{c}{ Dietary Na content, \% } & \multirow{2}{*}{ SEM } & $P$ \\
\cline { 2 - 5 } & 0.07 & 0.12 & 0.17 & 0.22 & & \\
\hline Tibia weight, $\mathrm{g}$ & $13.59^{\mathrm{c}}$ & $16.94^{\mathrm{b}}$ & $18.50^{\mathrm{b}}$ & $19.9^{\mathrm{a}}$ & 0.609 & $<0.001$ \\
Tibia length, $\mathrm{mm}$ & $122.0^{\mathrm{c}}$ & $130.7^{\mathrm{b}}$ & $136.1^{\mathrm{ab}}$ & $139.2^{\mathrm{a}}$ & 1.528 & $<0.001$ \\
Tibia perimeter, $\mathrm{mm}$ & $35.4^{\mathrm{b}}$ & $36.9^{\mathrm{b}}$ & $41.7^{\mathrm{a}}$ & $41.2^{\mathrm{a}}$ & 0.716 & $<0.001$ \\
Bone density index, $\mathrm{g} \cdot \mathrm{mm}^{-1}$ & $111.1^{\mathrm{b}}$ & $118.3^{\mathrm{b}}$ & $135.7^{\mathrm{a}}$ & $138.3^{\mathrm{a}}$ & 3.415 & 0.005 \\
Maximum elastic strength, $\mathrm{N}$ & $225^{\mathrm{b}}$ & $237^{\mathrm{b}}$ & $343^{\mathrm{a}}$ & $341^{\mathrm{a}}$ & 17.0 & 0.006 \\
Ultimate strength, $\mathrm{N}$ & $354^{\mathrm{b}}$ & $366^{\mathrm{ab}}$ & $433^{\mathrm{a}}$ & $490^{\mathrm{a}}$ & 16.3 & 0.003 \\
\hline
\end{tabular}

a,b,c values within a row with different letter differ significantly at $P \leq 0.05$

sodium levels deteriorated tibia composition and elasticity in broiler chickens. In the cited study, a sodium-deficient diet $(0.02 \%)$ fed to broilers caused a significant decrease in the crude ash and phosphorous content of tibia dry matter, which made the bones more brittle and more prone to break easily, but higher concentrations of $\mathrm{Na}$ in grower diets $(0.26 \%)$ also had an adverse impact on the parameters of tibia mineralization and breaking strength.

Table 4 presents selected results of an experiment that investigated the effects of different dietary sodium inclusion levels $(0.07 \%, 0.12 \%, 0.17 \%$ and $0.22 \%$ ) on the growth parameters, mineral composition, geometrical and mechanical properties of the tibia in turkeys.

The absolute weight of the tibia increased linearly with an increase in dietary Na levels $\left(R^{2}=\right.$ $0.904, P=0.045)$; the relative tibia weight (\% BW) was comparable in all groups, however (Jankowski et al., 2012a). The concentrations of crude ash, $\mathrm{Ca}$ and $\mathrm{P}$ in the tibia were similar in all treatments (data not shown). Tibia perimeter and density index were significantly higher in groups fed diets with a lower $\mathrm{Na}$ content $(0.07 \%$ and $12 \%)$ than in groups fed diets with higher Na levels $(0.17 \%$ and $0.22 \%)$. Increased dietary sodium (to $0.17 \%$ ) improved the maximum elastic strength and ultimate strength of the tibia, compared with groups fed diets with lower Na concentrations.

A different study (Jankowski et al., 2012b) analysed the growth rate, mineral composition, geometrical and mechanical properties of the tibia in turkeys fed diets with three levels of dietary $\mathrm{Na}$, $0.03 \%, 0.13 \%$ and $0.28 \%$. No significant differences were found among groups with respect to the content of ash, calcium and phosphorus in tibia dry matter. In comparison with the lowest level of dietary $\mathrm{Na}$, moderate sodium intake $(0.13 \%)$ improved tibia mineralization, maximum bending moment and maximum breaking strength. The highest level of dietary $\mathrm{Na}$ did not improve the analysed parameters compared with moderate $\mathrm{Na}$ intake. Moderate levels of dietary $\mathrm{Na}(0.13 \%$ and $0.17 \%)$ improved tibia mineralization in comparison with diets containing lower levels of $\mathrm{Na}(0.12 \%$ and less). An increase in $\mathrm{Na}$ content, from $0.17 \%$ to $0.22 \%$ and from $0.13 \%$ to $0.28 \%$, did not improve tibia growth, mineralization, or breaking strength.

Research results suggest that both sodium deficiency and excess may contribute to a lower degree of mineralization and a higher degree of porosity of the cortical bone in fast-growing chickens, compared with slow-growing birds (Leterrier and Nys, 1992; Wiliams et al., 2000).

\section{Effect of dietary Na \\ on the growth performance and slaughter quality of turkeys}

The results of experiments on broiler chickens indicate that an increase in the dietary $\mathrm{Na}$ content from $0.1 \%$ to $0.3 \%$ may lead to an improvement in the growth performance of broilers and feed conversion efficiency (Vieira et al., 2003; Borges et al., 2004; Mushtaq et al., 2007, 2010). According to some authors (Maiorka et al., 2004; Ribeiro et al., 2004), a higher $\mathrm{Na}$ level (over $0.40 \%$ ) is optimal for water consumption, feed intake and body weight gain. Koreleski et al. (2010) and Jankowski et al. (2011b) recommend a lower Na level, $0.15 \%$ and $0.12 \%-0.17 \%$, respectively, for starter diets, and $0.12 \%-0.16 \%$ and $0.11 \%$, respectively, for finisher diets.

Experimental turkeys are usually fed diets with a lower Na content (up to $0.30 \%$ ) than broiler chickens. The results of an experiment that covered the entire rearing cycle of turkeys are shown in Table 5. An increase in the Na content of diets from $0.07 \%$ to $0.22 \%$ led to an increase in the body weights of 8-week-old turkeys, whereas a further increase in dietary $\mathrm{Na}$ levels was not effective. Surprisingly, the live body weights of turkeys aged 18 weeks were similar in all groups, although the quadratic model describing the relationship between dietary $\mathrm{Na}$ levels and the final body weights of turkeys was nearly significant $\left(R^{2}=0.851, P=0.078\right)$. In the first 
stage of feeding, significantly $(P<0.001)$ higher feed conversion ratio (FCR) values were noted in the group fed a diet with the lowest $\mathrm{Na}$ content compared with the other groups. In the second stage of feeding (9-18 weeks), no significant differences in FCR were found between groups.

The above experiment (Table 5) involved male BUT-9 turkeys whose final body weights were relatively low, 14.16-14.54 kg, which could be the reason for the absence of significant differences in final body weight between groups. Such differences were observed in male BIG-6 turkeys (Jankowski et al., 2012c). The final body weights of 18 -week-old birds were close to $18 \mathrm{~kg}$; turkeys fed a diet with $0.08 \% \mathrm{Na}$ were characterized by significantly lower body weights, compared with birds that received $0.13 \%$ and $0.18 \% \mathrm{Na}$.

Table 5. Body weights and feed conversion ratio $\left(F C R, \mathrm{~kg} \mathrm{~kg}^{-1}\right)$ of turkeys fed diets with a different $\mathrm{Na}$ content (Jankowski et al., 2012c)

\begin{tabular}{|c|c|c|c|c|c|c|}
\hline \multirow{2}{*}{ Parameter } & \multicolumn{4}{|c|}{ Na content, \% } & \multirow{2}{*}{ SEM } & \multirow{2}{*}{$P$ value } \\
\hline & 0.07 & 0.12 & 0.17 & 0.22 & & \\
\hline \multicolumn{7}{|c|}{ Body weight, kg } \\
\hline at 8 week & $2.87^{\mathrm{b}}$ & $3.57^{\mathrm{a}}$ & $3.69^{a}$ & $3.77^{\mathrm{a}}$ & 0.073 & 0.001 \\
\hline at 18 weeks & 14.16 & 14.20 & 14.28 & 14.54 & 0.140 & 0.789 \\
\hline \multicolumn{7}{|c|}{ FCR } \\
\hline 1-8 weeks & $2.24^{a}$ & $1.95^{\mathrm{b}}$ & $1.86^{b}$ & $1.80^{\mathrm{b}}$ & 0.040 & 0.001 \\
\hline $1-18$ weeks & 2.74 & 2.66 & 2.63 & 2.64 & 0.038 & 0.342 \\
\hline
\end{tabular}

In a different study (Jankowski et al., 2012b), six-week-old turkeys fed a low-sodium diet $(0.03 \%)$ had average body weights of $1.06 \mathrm{~kg}$, while birds that received $0.13 \%$ and $0.28 \% \mathrm{Na}$ were significantly heavier (1.46 and $1.44 \mathrm{~kg}$, respectively). The present findings and the results of previous studies (Jankowski et al., 2012a,c) indicate that young turkeys (6 to 8 weeks of age) are more sensitive to dietary sodium deficiency than older birds at the end of rearing. In all experiments, an increase in the $\mathrm{Na}$ content of diets, from $0.12 \%$ to $0.17 \%$ and $0.22 \%$ (Jankowski et al., 2012c), from $0.13 \%$ to $0.28 \%$ (Jankowski et al., 2012b), and from $0.13 \%$ to $0.18 \%$ (Jankowski et al., 2012a), did not increase the final body weights of turkeys.

In a later experiment (Jankowski et al., 2012a), differences in dietary $\mathrm{Na}$ levels affected neither carcass dressing percentage nor the yields of thigh and shank. Dietary Na deficiency $(0.08 \%)$ decreased the growth rate of turkeys but had no effect on their slaughter quality. Meat colour parameters, $\mathrm{pH}$ and cooking loss were similar in all dietary treatments.

The results of the cited studies indicate that the recommendations of GfE (2004) more adequately reflect the actual sodium requirements of turkeys than the recommendations of the NRC (1994) and poultry breeding companies. In diets for younger turkeys, dietary sodium levels can be lowered to $0.13 \%, 0.12 \%$ and $0.10 \%$ at $1-4,5-8$ and $9-12$ weeks of age, respectively, and in older birds the $\mathrm{Na}$ content of diets can be maintained at $0.09 \%$.

\section{Physiological \\ and performance-related aspects of different Na sources in poultry diets}

Increasing interest in $\mathrm{Na}$ sources alternative to $\mathrm{NaCl}$ has resulted from the disruption of mineral and water balance observed in birds under conditions of heat stress (Ahmad and Sarwar, 2006; Mushtaq et al., 2007, 2013). It has also been found that high dietary $\mathrm{Na}$ and $\mathrm{Cl}$ levels exert a synergistic effect on increased water consumption, followed by elevated hydration of the intestinal contents and increased litter moisture (Mushtaq et al., 2005). As compared with $\mathrm{NaCl}$, which is inexpensive and commonly used in poultry nutrition, $\mathrm{NaHCO}_{3}$ has been claimed to be a good source of $\mathrm{Na}$ for birds since it has a beneficial influence on blood $\mathrm{pH}$ and $\mathrm{H}^{+}$ion balance (Mushtaq et al., 2013).

In a recent work of Jankowski et al. (2011a) reporting two experiments on broiler chickens fed diets with different levels of additional $\mathrm{Na}$ (up to $0.25 \%$ ), $\mathrm{NaHCO}_{3}$, and $\mathrm{Na}_{2} \mathrm{SO}_{4}$ (the latter in particular) significantly reduced excreta moisture and FPD scores. In an experiment on turkeys, the use of $\mathrm{NaHCO}_{3}$ and $\mathrm{Na}_{2} \mathrm{SO}_{4}$ as dietary alternatives to $\mathrm{NaCl}$ resulted in increased dry matter concentrations in the small intestinal and caecal contents, respectively (Jankowski et al., 2012a). In the cited study, a decrease in supplemental $\mathrm{Na}$ from $0.18 \%$ to $0.08 \%$ significantly reduced excreta moisture on day 112 , but the type of the applied salt had no influence on the above parameter. The type of $\mathrm{Na}$ salt had no effect on the final body weights of turkeys, either. Differences in the growth rate of turkeys were observed in successive phases of feeding. In the first feeding period ( $0-4$ weeks), body weight gains were significantly higher in the $\mathrm{NaCl}$ treatment relative to $\mathrm{NaHCO}_{3}$ and $\mathrm{Na}_{2} \mathrm{SO}_{4}$ salts; an opposite trend was observed in the final $13-18$ weeks of feeding $(\mathrm{NaCl}$ $<\mathrm{NaHCO}_{3}$ and $\mathrm{Na}_{2} \mathrm{SO}_{4}$ ). In the first two phases of feeding, an interaction for FCR was noted: in weeks $0-4$, the highest FCR values were noted for the $0.08 \% \mathrm{Na}$ dosage in all three salt types; at the medium $(0.13 \%)$ dietary additional Na level, an increase in FCR was observed in turkeys fed a diet with $\mathrm{NaHCO}_{3}$ compared with those receiving an $\mathrm{NaCl}-$ 
supplemented diet. In weeks $5-8$, the highest FCR value was determined in the group fed a diet supplemented with the lowest dosage of $\mathrm{NaCl}$. In the final phase of feeding (13-18 weeks), no differences in FCR were observed between groups. This confirms that the effect of different dietary sodium levels is more pronounced in the first weeks of the rearing period, and becomes weaker as turkeys grow older.

The breast muscles of turkeys fed diets containing $\mathrm{NaHCO}_{3}$ and $\mathrm{Na}_{2} \mathrm{SO}_{4}$ were lighter in colour than the breast muscles of birds receiving $\mathrm{NaCl}$ (Jankowski et al., 2012a). This finding, similarly as the beneficial influence of alternative sodium sources on gastrointestinal function and excreta moisture in turkeys should, nevertheless, be confirmed in a follow-up study.

In the discussed experiment, $\mathrm{Na}$ sources alternative to $\mathrm{NaCl}$ contributed to a significant increase in DEB, from about 250 to $300 \mathrm{meq} \cdot \mathrm{kg}^{-1}$ in the first month, and from about $150 \mathrm{meq} \cdot \mathrm{kg}^{-1}$ to $200 \mathrm{meq} \cdot \mathrm{kg}^{-1}$ in the final stage of rearing. DEB decreased in response to a decrease in $\mathrm{Cl}$ content, from $0.3 \%-0.4 \%$ in $\mathrm{NaCl}$-supplemented diets to $0.14 \%-0.16 \%$ in diets with $\mathrm{NaHCO}_{3}$ and $\mathrm{Na}_{2} \mathrm{SO}_{4}$. It remains unknown whether the noted physiological changes resulted from higher DEB values or a reduced $\mathrm{Cl}$ content of turkey diets. Hooge et al. (1999) reported that DEB values may increase or decrease due to variation in electrolyte levels, which makes it difficult to identify the mechanism underlying the observed physiological responses of birds.

The original research results presented briefly in this review demonstrate that young turkeys (to 8 weeks of age) respond to a sodium-deficient diet $(0.08 \%$ and less) by reduced growth, but their body weights do not increase in response to dietary sodium increased above the NCR (1994) recommendations. An increase in the Na content of turkey diets above the recommended limits has no positive effect on bone mineralization and increases the risk of footpad dermatitis in young birds. The use of $\mathrm{NaHCO}_{3}$ and $\mathrm{Na}_{2} \mathrm{SO}_{4}$ as alternatives to $\mathrm{NaCl}$ in turkey diets with lower Na inclusion levels, when Na has a limited effect on excreta moisture, should be investigated in a further study.

\section{References}

Abd El-Wahab A., Visscher C.F., Beineke A., Beyerbach M., Kampheus J., 2011. Effect of high electrolyte contents in the diet and using floor heating on development and severity of foot pad dermatitis in young turkeys. J. Anim. Physiol. Anim. Nutr. 97, 39-47

Ahmad T., Sarwar M., 2006. Dietary electrolyte balance: Implications in heat stressed broilers. World Poultry Sci. J. 62, 638-653
Arantes U.M., Stringhini J.H., Oliveira M.C., Martins P.C., Rezende P.M., Andrade M.A., Leandro N.S.M., Café M.B., 2013. Effect of different electrolyte balances in broiler diets. Rev. Bras. Cienc. Avic. 15, 169-286

Aviagen Turkeys, 2014. Management Essentials for Commercial Turkeys. http://www.aviagenturkeys.com (accessed 20.02.14)

Borges S.A., Fischer da Silva A.V., Ariki J., Hooge D.M., Cummings K.R., 2003. Dietary electrolyte balance for broiler chickens under moderately high ambient temperatures and relative humidities. Poultry Sci. 82, 301-308

Borges S.A., Fischer da Silva A.V., Majorka A., Hooge D.M., Cummings K.R., 2004. Physiological response of broiler chickens to heat stress and dietary electrolyte balance (sodium plus potassium minus chloride, milliequivalents per kilogram). Poultry Sci. 83, 1551-1558

Buehlmeier J., Frings-Meuthen P., Remer T., Maser-Gluth C., Stehle P., Biolo G., Heer M., 2012. Alkaline salts to counteract bone resorption and protein wasting induced by high salt intake: results of a randomized controlled trial. J. Clin. Endocrinol. Metab. 97, 4789-4797

Cengiz Ö., Hess J.B., Bilgili S.F., 2012. Influence of graded levels of dietary sodium on the development of footpad dermatitis in broiler chickens. J. Appl. Poultry Res. 21, 770-775

Cowieson A.J., Bedford M.R., Ravindran V., Selle P.H., 2011. Increased dietary sodium chloride concentrations reduce endogenous amino acid flow and influence the physiological response to the ingestion of phytic acid by broiler chickens. Brit. Poultry Sci. 52, 613-624

Crespo R., Stover S.M., Taylor K.T., Chin R.P., Shivaprasad H.L., 2000. Morphometric and mechanical properties of femora in young adult male turkeys with and without femoral fractures. Poultry Sci. 79, 602-608

Daniels D., Yee D.K., Fluharty S.J., 2007. Angiotensin II receptor signalling. Exp. Physiol. 92, 523-527

Eichner G., Vieira S.L., Torres C.A., Coneglian J.L.B., Freitas D.M., Oyarzabal O.A., 2007. Litter moisture and footpad dermatitis as affected by diets formulated on an all-vegetable basis or having the inclusion of poultry by-product. J. Appl. Poultry Res. 16, 344-350

Ekanayake S., Silva S.S., Priyankarage N., Herath U.T., Jayasekara M.U., Horadagoda N.U., Abeynayake P., Gunaratne S.P., 2004. Effect of excess sodium in feed on haematological parameters and plasma sodium level in broiler chickens. Brit. Poultry Sci. 45, Suppl. 1, 53-54

Enting H., De Los Mozos J., Gutierrez Del Alamo A., Perez de Ayala P., 2009. Influence of minerals on litter moisture. Proceedings of $17^{\text {th }}$ European Symposium on Poultry Nutrition. Edinburg, pp. 47-52

Faruga A., Pydynkowska K., Jankowski J., Kozłowski K., Płudowski P., 2009. Comparison of the effect of cholecalciferol and 25-hydroxycholecalciferol on the characteristic features of femoral and tibia bones in male fattening turkeys. Arch. Geflügelk. 73, 237-241

Frame D.D., Hooge D.M., Cutler R., 2001. Interactive effects of dietary sodium chloride on the incidence of spontaneous cardiomyopathy (Round Heart) in turkeys. Poultry Sci. 80, 1572-1577

Francesch M., Brufau J., 2004. Nutritional factors affecting excreta/ litter moisture quality. World Poultry Sci. J. 60, 64-75

Frassetto L.A., Morris Jr. R.C., Sellmeyer D.E., Sebastian A., 2008. Adverse effects of sodium chloride on bone in the aging human population resulting from habitual consumption of typical American diets. J. Nutr. 138, 419-422

Gal-Garber O., Mabjeesh S.J., Sklan D., Uni Z., 2003. Nutrient transport in the small intestine $\mathrm{Na}^{+}, \mathrm{K}^{+}$-ATPase expression and activity in the small intestine of the chicken as influenced by dietary sodium. Poultry Sci. 82, 1127-1133 
GfE, 2004. Nutrient Requirements of Turkeys (in German). In: Proceedings of the Society of Nutrition Physiology 13, 199-233

Hooge D.M., Cummings K.R., Mcnaughton J.L., 1999. Evaluation of sodium bicarbonate, chloride, or sulfate with coccidiostats in corn-soy or corn-soy-meat diets for broilers chickens. Poultry Sci. $78,1300-1306$

Hybrid Turkeys, 2014. Commercial Management Guide. Nuritional Guidelines. http://www.hybridturkeys.com (accessed 20.02.14)

Jankowski J., Juśkiewicz J., Gulewicz K., Lecewicz A., Slominski B.A., Zduńczyk Z., 2009. The effect of diets containing soybean meal, soybean protein concentrate and soybean protein isolate of different oligosaccharide content on growth performance and gut function of young turkeys. Poultry Sci. 88, 2132-2140

Jankowski J., Juśkiewicz J., Lichtorowicz K., Zduńczyk Z., 2012a. Effects of the dietary level and source of sodium on growth performance, gastrointestinal digestion and meat characteristics in turkeys. Anim. Feed Sci. Tech. 178, 74-83

Jankowski J., Juśkiewicz J., ZduńczykZ., Śmiecińska K., Kwieciński P., 2011a. Effects of the inclusion level and source of dietary sodium from different sodium salts on performance and meat characteristics of broiler chickens. Arch. Anim. Nutr. 65, 186-202

Jankowski J., Lichtorowicz K., Zduńczyk Z., Juśkiewicz J., 2012b. The effect of different dietary sodium levels on blood mineral concentrations and tibia mineralization in turkeys. Pol. J. Vet. Sci. $15,227-232$

Jankowski J., Zduńczyk Z., Juśkiewicz J., Kwieciński P., 2011b. Effect of different dietary sodium levels on the growth performance of broiler chickens, gastrointestinal function, excreta moisture and tibia mineralization. J. Anim. Feed Sci. 20, 93-106

Jankowski J., Zduńczyk Z., Lichtorowicz K., Juskiewicz J., 2012c. Effect of different levels of dietary sodium from sodium chloride on gastrointestinal tract response, tibia mineralization, and footpad dermatitis incidence in young turkeys. J. Appl. Poultry Res. 21, 856-867

Jankowski J., Zduńczyk Z., Mikulski D., Przybylska-Gornowicz B., Sosnowska E., Juśkiewicz J., 2013. Effect of whole wheat feeding on gastrointestinal tract development and performance of growing turkeys. Anim. Feed Sci. Tech. 185, 150-159

Johnson A.K., 2007. The sensory psychobiology of thirst and salt appetite. Med. Sci. Sport. Exercise 39, 1388-1400

Kaplan J.H., 2002. Biochemistry of Na,K-ATPase. Annu. Rev. Biochem. 71, 511-535

Kaplan J.H., 2008. Natriuretic hormone-binding site on the sodium pump. J. Amer. Soc. Nephrol. 19, 1839-1840

Kestin S.C., Gordon S., Su G., Sorennsen P., 2001. Relationship in broiler chicken between lameness, liveweight, growth rate and age. Vet. Rec. 148, 195-197

Koreleski J., Świątkiewicz S., Arczewska A., 2010. The effect of dietary potassium and sodium on performance, carcass traits, and nitrogen balance and excreta moisture in broiler chicken. J. Anim. Feed Sci. 19, 244-256

Koreleski J., Światkiewicz S., Arczewska A., 2011. The effect of dietary potassium and sodium on performance and excreta dry matter in broiler chicken. Czech. J. Anim. Sci. 56, 53-60

Lara L.J., Rostagno M.H., 2013. Impact of heat stress on poultry production. Animal 3, 356-369

Leshchinsky T.V., Klasing. K.C., 2001. Divergence of the inflammatory response in two types of chickens. Develop. Comp. Immunol. $25,629-663$

Leterrier C., Nys Y., 1992. Composition, cortical structure and mechanical properties of chicken tibiotarsi: effect of growth rate. Brit. Poultry Sci. 39, 925-939

Lichtorowicz K., Jankowski J., Zduńczyk Z., Juśkiewicz J., 2012. The effect of different dietary sodium levels on blood electrolytes, growth performance and foot pad dermatitis incidence in turkeys. J. Elem. 17, 279-287
Maiorka A., Masgro N., Bartels H.A., Kessler A.M., Penz Jr. A.M., 2004. Different sodium levelsand electrolyte balance in prestarter diet for broilers. Rev. Bras. Cien. Avic. 6, 143-146

Mayne R.K., Else R.W., Hocking P.M., 2007. High litter moisture alone is sufficient to cause footpad dermatitis in growing turkeys. Brit. Poultry Sci. 48, 538-545

Mongin P., 1980. Electrolytes in Nutrition. $3^{\text {rd }}$ International Minerals Conference. Orlando, pp. 1-16

Mongin P., 1981. Recent advantages in dietary anion-cations balance: Applications in poultry. Proc. Nutr. Soc. 40, 285-294

Morris M.J., Na E.S., Johanson A.K., 2008. Salt craving: The psychobiology of pathogenic sodium intake. Pysiol. Behav. 94, 709-721

Murakami A.E., Oviedo-Rondon E.O., Martins E.N., Pereira M.S. Scapinello C., 2001. Sodium and chloride requirements of growing broiler chickens (twenty-one to forty-two days of age) fed corn-soybean diets. Poultry Sci. 80, 289-294

Murakami A.E., Saleh E.A., England J.A., Dickey D.A., Watkins S.E., Waldroup P.W., 1997b. Effect of level and source of sodium on preformance of male broilers to 56 days. J. Appl. Poultry Res. 6, 128-136

Murakami A.E., Watkins S.E., Saleh E.A., England J.A., Waldroup P.W., 1997a. Estimation of the sodium and chloride requirements for the young broiler chick. J. Appl. Poultry Res. 6, 155-162

Mushtaq T., Aslam Mirza M., Athar M., Hooge D.M., Ahmad T., Ahmad G., Mushtaq M.M.H., Noreen U., 2007. Dietary sodium and chloride for twenty-nine to forty-two-day-old broiler chickens at constant electrolyte balance under subtropical summer conditions. Appl. Poultry Res. 16, 161-170

Mushtaq T., Pasha T.N., 2013. Electrolyte, dietary electrolytes balance and salts in broilers: an updates review on acid-base balance, blood and carcass characteristics. World Poultry Sci. J. 69 , 833-851

Mushtaq T., Pasha T.N., Mushtaq M.M.H., Parvin R., 2013. Electrolyte, dietary electrolytes balance and salts in broilers: an updates review on growth performance, water intake and litter quality. World Poultry Sci. J. 69, 789-802

Mushtaq T., Sarwar M., Nawaz H., Aslam Mirza M., Ahmad T., 2005. Effect on interactions of dietary sodium and chloride on broiler starter performance (hatching to twenty-eight days of age) under subtropical summer conditions. Poultry Sci. 84, 1716-1722

Nääs I.A., Paz I.C.L.A., Baracho M.S., Menezes A.G., Bueno L.G.F., Amleida I.C.I., Moura D.J., 2009. Impact of lameness on broiler well-being. J. Appl. Poultry Res. 18, 432-439

NRC, 1994. Nutrient Requirements of Poultry. $9^{\text {th }}$ revised Edition. National Academy Press. Washington, DC

Olanrewaju H.A., Thaxton J.P., Dozier W.A., Branton S.L., 2007. Electrolyte diets, stress, and acid-base balance in broiler chickens. Poultry Sci. 86, 1363-1371

Oviedo-Rondon E.O., Ferket P.R., Havestin G.B., 2006. Nutritional factors that affect leg problems in broilers and turkeys. Avian Poultry Biol. Rev. 17(3), 89-103

Pang C.Y., Phillips W.H., Campbell L.D., 1979. The toxic effect of saline drinking water on young turkey poults. Brit. Poultry Sci. 20,1-7

Rao R.S.V., Raju M.V.L.N., Sharma R.P., Nagalakshmi D., Reddy M.R., 2003. Lameness in chickens: alleviation by dietary manipulation. Poultry Int. 42, 56-61

Ribeiro A.M.L., Krabbe E.L., Penz Jr. A.M., Renz S.V., Gomes H.A., 2004. Effect of chick weight, geometric mean diameter and sodium level in prestarter diets ( 1 to 7 days) on broiler performance up to 21 days of age. Rev. Bras. Cien. Avic. 6, 225-230

Sandercock D.A., Mitchel M.A., 2004. The role of sodium ions in the pathogenesis of skeletal muscle damage in broiler chickens. Poultry Sci. 87, 701-706 
Szabó J., Vucskits A.V., Andrásofszky E., Berta E., Bersényi A., Börzsönyi L., Pálfi V., Hullár l., 2011. Effect of dietary electrolyte balance on production, immune response and mineral concentrations of the femur in broilers. Acta Vet. Hung. 59, 295-310

Tatara M.R, Krupski W., Jankowski M., Zduńczyk Z., Jankowski J., Studziński T., 2011. Effects of dietary calcium content and vitamin D source on skeletal properties in growing turkeys. Brit. Poultry Sci. 52, 718-729

Therien A., Blostein C., 2000. Mechanism of sodium pump regulation. Amer. J. Physiol. 279, 541-566

Tykałowski B., Stenzel T., Mikulski D., Jankowski J., Zduńczyk Z., Juskiewicz J., Koncicki A., 2011. Level of electrolytes and percentage of T-lymphocyte subpopulations in blond of broiler chickens fed mixtures with different contents of sodium chloride. Bull. Vet. Inst. Pulawy 55, 333-337

Venäläinen E., Valaja J., Jalava T., 2006. Effect of dietary metabolisable energy, calcium and phosphorus on bone mineralization, leg weakness and performance of broiler chickens. Brit. Poultry Sci. 47, 301-310

Vieira S.L., Penz A.M., Pophal S., Godoy de Almeida J., 2003. Sodium requirements for the first seven days in broiler chicks. J. Appl. Poultry Res. 12, 362-370
Watkins, S.E., Fritts C.A., Yan F., Wilson M.L., Waldroup P.W., 2005. The interaction of sodium chloride levels in poultry drinking water and the diet of broiler chickens. J. Appl. Poultry Res. $14,55-59$

Wiliams, B., Solomon S., Waddington D., Throp B., Farquarson C., 2000. Skeletal development in the meat-type chicken. Brit. Poultry Sci. 41, 141-149

Zduńczyk Z., Jankowski J., Juskiewicz J., Kwiecińcki P., 2012. The response of the gastrointestinal tract of broiler chickens to different dietary levels and sources of sodium. Vet. Med. Zoot. 60(82), 92-98

Zduńczyk Z., Jankowski J., Mikulski D., Przybylska-Gornowicz B., Sosnowska E., Juśkiewicz J., 2013. Gastrointestinal morphology and function in turkeys fed diets diluted with whole grain wheat. Poultry Sci. 92, 1799-1811

Zhou Z.L., Rath N.C., Huff G.R., Huff W.E., Rasaputra, Salas C., Coon C.N., 2011. Bone characteristics of 16 wk-old-turkeys subjected to different dietary supplements and stimulated stress. Int. J. Poultry Sci. 10, 332-337 